\title{
Contractvrijheid voor de bank? Opzegging van een betaalrekening
}

\author{
Mr. I.S.J. Houben*
}

1 Inleiding

Het thema vrijheid vertaalt zich met een contractenrechtelijke blik al snel in contractvrijheid. 75 jaar bevrijding geeft ook direct het markeringspunt aan, namelijk het daaraan voorafgaande niet vrij zijn, dwang ondervinden. In het contractenrecht zijn (contract)vrijheid en (contract)dwang de keerzijden van dezelfde medaille.

Enige jaren geleden verdiepte ik mij in contractdwang voor banken en stelde ik de vraag of er een recht op een bankrekening bestond. ${ }^{1}$ Het antwoord luidde toen bevestigend. Al was er toentertijd nog geen sprake van een wettelijke regeling, ${ }^{2}$ de contractvrijheid van de bank werd in sterke mate beperkt ten behoeve van het belang van toegang tot bancaire diensten, zelfs in die mate dat van contractdwang kon worden gesproken. Inmiddels bestaat er een wettelijk recht op een basisbetaalrekening op grond van de Europese betaalrekeningrichtlijn, ${ }^{3}$ geimplementeerd in art. 4:71f t/m 4:71j Wft. ${ }^{4}$ Hiermee zijn niet alle vragen inzake het recht op een bankrekening beantwoord. Een vraag die de afgelopen maanden tot aandacht in de media leidde, is welke vrijheid banken hebben om het aangaan van een betaalrekening te weigeren of een reeds bestaande rekening op te heffen. De vraag rees op meerdere fronten. Zo gaven banken aan zich in een aantal gevallen genoodzaakt te zien bankrekeningen op te heffen van Nederlanders die tevens de Amerikaanse nationaliteit hebben en daarom ingevolge Amerikaanse wetgeving belastingaangifte moeten doen.' Op grond van een 'Intergovernmental Agreement' (IGA) met de Verenigde Staten (VS) vragen Nederlandse banken het Amerikaanse 'social security number' (ssn)

* Mr. I.S.J. Houben is universitair hoofddocent bij de afdeling civiel recht, Universiteit Leiden.

1. I.S.J. Houben, Recht op een bankrekening, VrA 2009/1.1.

2. Wel was er een nationale regeling in voorbereiding, die vooruitliep op de Europese regelgeving. Zie daarover M.L. Louisse, Het wettelijk recht op een betaalrekening is een feit, maar wel een zeer beperkt feit, $\mathrm{V} \& \mathrm{O}$ 2013, p. 11-15.

3. Richtlijn 2014/92/EU van het Europees Parlement en de Raad van 23 juli 2014 betreffende de vergelijkbaarheid van de in verband met betaalrekeningen aangerekende vergoedingen, het overstappen naar een andere betaalrekening en de toegang tot betaalrekeningen met basisfunctie, PbEU 2014, L 257/214.

4. Zie over de richtlijn en de implementatie in Nederland R.M.C. Philipsen, Toegang tot een basisbetaalrekening in Nederland na implementatie van de 'Payment Account Directive', FR 2014, afl. 10, p. 392-398.

5. Foreign Account Tax Compliance Act (FATCA), een wet waarmee de VS proberen te bewerkstelligen dat Amerikanen in het buitenland aan hun aangifteplicht voldoen. of 'taxpayer identification number' (tin) van hun klanten op, ten behoeve van de belastingdienst in de VS. De banken zijn van mening dat zij op grond van het hiervoor genoemde IGA het risico lopen bloot te staan aan aanzienlijke sancties indien zij een rekening in stand houden met een klant die de gevraagde informatie niet verstrekt. ${ }^{6}$ Ofschoon de staatssecretaris inmiddels in antwoord op Kamervragen heeft aangegeven van mening te zijn dat een betaalrekening niet mag worden opgezegd vanwege het niet verstrekken van de genoemde gegevens en dat sancties niet direct aan de orde zijn, ${ }^{7}$ geeft het voorbeeld aan dat wellicht ook voor de bank niet steeds duidelijk is of zij in een concreet geval mag weigeren een rekening te openen of mag opzeggen. ${ }^{8}$ Een ander voorbeeld dat de krant haalde, was het geval waarin ABN AMRO door de rechter veroordeeld werd aan een cannabisteler een betaalrekening te verschaffen. ${ }^{9}$ De bank had dat geweigerd vanwege het zogenaamde integriteitsrisico, maar de rechter vond dat niet voldoende aannemelijk was gemaakt dat het in dit geval een reëel risico betrof. De cannabisteler in kwestie was een speciaal voor het landelijke 'Experiment gesloten cannabisketen' opgerichte vennootschap, Project C genaamd. En de krant De Limburger kopte in januari 2020: 'Gerechtshof: ING mag saunaclub Yin

6. FD 6 april 2020, p. 23 en www.nvb.nl/themas/bank-maatschappij/fatca. Veel van deze klanten hebben nooit een ssn of tin aangevraagd. De Amerikaanse nationaliteit kan verkregen zijn omdat een van de ouders Amerikaan is, of omdat de klant in de VS geboren is, zonder dat de betreffende klant ooit in de VS heeft gewoond of gewerkt. Sommige klanten waren zich niet bewust van hun dubbele nationaliteit, totdat zij geconfronteerd werden met de mogelijke opheffing van hun betaalrekening. De sanctie waarmee de Amerikanen dreigen, is het heffen van $30 \%$ op inkomsten uit Amerikaanse bron bij de bank. Zie over de FATCA en de IGA nader C. van Dijk, 'Recalcitrant account holders' in de IGA, WFR 2019/82 en C. van Dijk, Intergovernmental Agreement FATCA, WFR $2019 / 214$. Van Dijk is - kort gezegd - van mening dat de IGA geen sluiting van rekeningen voorschrijft.

7. De staatssecretaris baseert zich mede op adviezen ter zake van AFM en DNB. Brief d.d. 19 maart 2020 betreffende beantwoording Kamervragen FATCA, www.rijksoverheid.nl/ministeries/ministerie-vanfinancien/documenten/kamerstukken/2020/03/19/kamerbriefbeantwoording-kamervragen-fatca.

8. Vgl. Rb. Amsterdam (vzr.) 6 februari 2020, ECLI:NL:RBAMS: 2020:893 inzake de vraag of de (Amerikaanse) boycot van Cuba kan leiden tot een verhoogd risicoprofiel en opzegging van de bankrekening van klanten die met Cuba handelen.

9. C. Paauwe, ABN Amro moet bankrekening openen voor wietondernemers, NRC 4 november 2019, n.a.v. Rb. Amsterdam (vzr.) 4 november 2019, ECLI:NL:RBAMS:2019:8144. 
Yang geen bankrekening weigeren'. ${ }^{10}$ Yin Yang is, zoals het arrest van het gerechtshof Amsterdam vermeldt, 'een ontmoetingsplaats in de relaxbranche' en de ING zag hierin een integriteitsrisico. Het hof veroordeelt de bank evenwel om Yin Yang in staat te stellen een betaalrekening bij haar aan te houden.

Deze casus doen de vraag rijzen onder welke voorwaarden een bank mag weigeren een betaalrekening te openen of een reeds geopende betaalrekening mag opzeggen. De integriteitsregels waaraan de bank zich moet houden, kunnen reden zijn voor een dergelijke weigering of opzegging, waarover meer in de volgende paragrafen. Ik concentreer mij in deze bijdrage op de opzegging van een overeenkomst inzake betaaldiensten, maar ook de weigering om de overeenkomst aan te gaan komt zijdelings aan bod. De voorwaarden waaronder een betaalrekening mag worden geweigerd, zullen deels overlappen met de voorwaarden waaronder mag worden opgezegd. Het ligt voor de hand dat indien contractdwang bestaat bij het aangaan van de overeenkomst inzake betaaldiensten, die overeenkomst vervolgens niet zonder meer kan worden opgezegd. Dat zou de contractdwang, en met name de bescherming die hij beoogt te bieden, illusoir maken. ${ }^{11}$

\section{Opening en opzegging basisbetaalrekening}

Het hiervoor genoemde recht op een basisbetaalrekening is een recht voor consumenten om een basisbetaalrekening aan te vragen en te gebruiken. Een basisbetaalrekening wordt in art. 1:1 Wft omschreven als een betaalrekening, met inbegrip van bijbehorende betaalinstrumenten, waarbij debetstand niet mogelijk is. De basisbetaalrekening is dus een minimumvoorziening. De consument die de aanvraag doet, hoeft niet de Nederlandse nationaliteit te hebben of in Nederland te wonen, maar dient wel rechtmatig in de EU te verblijven. ${ }^{12}$ Ook consumenten die geen vast adres hebben of in afwachting zijn van een asielaanvraag of die niet kunnen worden uitgezet, hebben recht op een dergelijke basisbetaalrekening. ${ }^{13}$

10. R. Koumans, Gerechtshof: ING mag saunaclub Yin Yang geen bankrekening weigeren, De Limburger 27 januari 2020, n.a.v. Hof Amsterdam 21 januari 2020, ECLI:NL:GHAMS:2020:121.

11. In de jaren zeventig van de vorige eeuw werd het al dan niet geoorloofd zijn van contractweigering door banken, juist vanwege het belang van de toegang tot hun dienstverlening, al bediscussieerd. Deze discussie vond plaats onder meer naar aanleiding van de voorgenomen weigering van $\mathrm{ABN}$ om rekeningen te openen voor klanten die afkomstig waren van de AMRObank. Deze klanten hadden daar zelf hun rekening opgezegd uit protest tegen de weigering van AMRObank om een boycot tegen (het apartheidsregime in) Zuid-Afrika te steunen door kredieten t.b.v. handelstransacties met dat land op te zeggen. Uit solidariteit met de AMRObank gaf $\mathrm{ABN}$ aan deze klanten niet zonder meer te zullen accepteren. Zie o.m. W.J. Slagter, Privaatrechtelijke boycot en publiekrechtelijk boycot, NJB 1976, p. 1219-1227; R. de Winter, ZuidAfrika, de banken en de boycot van de boycot, NJB 1977, p. 65-70; P.A.M. Meijknecht, Boycot als strijdmiddel bij politieke acties onrechtmatig?, NJB 1977, p. 70-73; J.J. Nagelkerke, De weigering door een bankinstelling om een rekening te openen: een vorm van tegenboycot?, NJB 1977, p. 789-794.

12. Art. 4:71 lid $1 \mathrm{Wft}$.

13. Art. 4:71 lid $2 \mathrm{Wft}$
Een basisbetaalrekening omvat de diensten, genoemd in art. 17 lid 1 van de richtlijn betaalrekeningen, voor zover de aangezochte bank die diensten ook aanbiedt aan consumenten die een andere betaalrekening dan een basisbetaalrekening aanhouden bij de betreffende bank. ${ }^{14}$ Het gaat om banken die in Nederland reguliere betaalrekeningen aan consumenten aanbieden. De bank hoeft dus niet de dienstverlening speciaal voor consumenten die een basisbetaalrekening wensen op te tuigen.

De genoemde diensten betreffen de volgende mogelijkheden om een betaalrekening te gebruiken. Het gaat ten eerste om diensten waarmee alle verrichtingen kunnen worden uitgevoerd die nodig zijn voor het openen, gebruiken en beëindigen van een betaalrekening. Voorts betreft het diensten waarmee geldmiddelen op een bankrekening kunnen worden gestort en, binnen de EU, contant geld aan het loket of bij een geldautomaat kan worden opgenomen. Ook dienen binnen de EU automatische afschrijvingen en betalingstransacties via een betaalkaart, daaronder begrepen online betalingen, mogelijk te zijn. Verder dient het binnen de EU mogelijk te zijn om overmakingen te verrichten, met inbegrip van doorlopende opdrachten aan, indien beschikbaar, terminals en loketten en via het internetplatform van de kredietinstelling. ${ }^{15}$

De bank moet de basisbetaalrekening binnen een termijn van tien werkdagen na ontvangst van een volledige aanvraag openen. De bank mag het openen van een basisbetaalrekening weigeren op specifiek in de $\mathrm{Wft}$ genoemde, limitatieve, gronden. ${ }^{16}$ Die gronden zijn in de eerste plaats gelegen in eisen die worden gesteld in de Wet ter voorkoming van witwassen en financieren van terrorisme (Wwft). Verder mag een bank het openen van een basisbetaalrekening weigeren als de aanvrager niet kan aantonen een werkelijk belang te hebben bij het openen van een dergelijke rekening in Nederland, als de aanvrager al bij een andere bank een betaalrekening heeft (tenzij deze zal worden opgeheven), of al een aanvraag heeft lopen. Weigering is ook geoorloofd als de aanvrager minder dan acht jaar geleden onherroepelijk is veroordeeld voor bepaalde misdrijven, te weten valsheid in geschrifte, bedrog, bedrieglijke bankbreuk of witwassen, of als de aanvrager al een basisbetaalrekening had die minder dan twee jaar geleden is beëindigd omdat de rekening opzettelijk is gebruikt voor het plegen van misdrijven. De aanvrager mag worden gevraagd om een verklaring te tekenen dat hij geen andere betaalrekening aanhoudt of heeft aangevraagd in Nederland. ${ }^{17}$ Ook worden eisen gesteld aan de kosten die de bank mag rekenen voor de basisbetaalrekening: de diensten dienen kosteloos of tegen een redelijke vergoeding te worden aangeboden. ${ }^{18}$ In geval van niet-nakoming van de verbintenissen uit hoofde van de raamovereen-

14. Art. 4:71 lid $3 \mathrm{Wft}$.

15. Art. 17 Richtlijn 2014/92/EU, PbEU 2014, L 257/214.

16. Art. 4:71f lid $4 \mathrm{Wft}$. In geval van een weigering dient de bank de aanvrager op de hoogte te stellen van de klachtenprocedure en de mogelijkheid een klacht in te dienen bij het Kifid of de AFM, art. 4:71h Wft.

17. Art. 4:71g Wft.

18. Art. 4:71flid $7 \mathrm{Wft}$. 
komst voor betaaldiensten mag de bank niet meer dan een redelijke vergoeding in rekening brengen.

Art. 4:71i Wft heeft betrekking op het beëindigen van een basisbetaalrekening. De bank kan een overeenkomst met de houder van de basisbetaalrekening of een raamovereenkomst waarin toegang tot een basisbetaalrekening wordt geregeld eenzijdig beëindigen op bepaalde, limitatief opgesomde, gronden. Die gronden overlappen deels met de weigeringsgronden ex art. 4:71g Wft, die hiervoor werden besproken. De beëindigingsgronden zijn dat de rekeninghouder langer dan 24 maanden geen transacties meer heeft verricht op de basisbetaalrekening of een tweede betaalrekening heeft bij een andere in Nederland gevestigde bank, waarmee hij basisbetaaldiensten kan verrichten. Ook indien de klant niet langer rechtmatig in de EU verblijft, vormt dat een reden tot weigering. Datzelfde geldt voor de klant die onherroepelijk is veroordeeld voor bepaalde misdrijven, voornamelijk betrekking hebbend op fraude in ruime zin en witwassen (het betreft dezelfde misdrijven als die in art. 4:71g Wft inzake het openen van een basisbetaalrekening worden genoemd). Ook indien de klant onjuiste of onvolledige informatie heeft verstrekt om toegang tot de basisbetaalrekening te verkrijgen, terwijl die informatie een weigeringsgrond zou hebben opgeleverd, of indien de klant de basisbetaalrekening opzettelijk heeft gebruikt voor het plegen van strafbare feiten, kan de bank de overeenkomst eenzijdig beëindigen. Bij een beëindigingsgrond ex art. 4:71i lid 1 sub a, b of c Wft, dat wil zeggen het niet gebruiken van de rekening, het hebben van een tweede betaalrekening of niet langer rechtmatig in de EU verblijven, geldt een opzegtermijn van twee maanden. ${ }^{19}$ Gaat het om een beëindigingsgrond ex art. 4:71i lid 1 sub $\mathrm{d}$, e of $\mathrm{f} \mathrm{Wft}$, dat wil zeggen veroordeling voor een van de genoemde misdrijven, onjuiste informatieverstrekking of het opzettelijk gebruik van de rekening voor het plegen van strafbare feiten, dan beëindigt de bank de overeenkomst onmiddellijk. ${ }^{20} \mathrm{Ik}$ ga er, mede vanwege de vermelding van een opzegtermijn, van uit dat met de term beëindiging gedoeld wordt op het opzeggen van de overeenkomst en niet op overige wijzen van beëindiging, zoals vernietiging of ontbinding.

De consument kan zich bij klachten over de weigering of opzegging van een basisbetaalrekening tot toezichthouder AFM wenden, alsmede tot het Kifid. ${ }^{21}$ De AFM zal niet bemiddelen in een individueel geval, maar mochten haar meerdere klachten bereiken, dan zal zij als toezichthouder de bank(en) kunnen aanspreken. ${ }^{22}$ De route via de toezichthouder biedt dus geen garanties voor een (snelle) oplossing in het individuele geval. ${ }^{23}$ Daarvoor is de gang naar het Kifid de eerst

19. Art. 4:71i lid $2 \mathrm{Wft}$

20. Art. 4:71i lid $3 \mathrm{Wft}$.

21. Art. $4: 71 \mathrm{~h}$ lid 3 en $4: 71 \mathrm{i}$ lid $4 \mathrm{Wft}$.

22. Kamerstukken II 2015/16, 34480, nr. 3 .

23. Zie over het verschil tussen publiek- en privaatrechtelijke handhaving nader C.A. Hage, Handhaving van privaatrecht door toezichthouders (diss. Leiden), Deventer: Wolters Kluwer 2017, p. 283-424 (hoofdstuk 5 'AFM als handhaver van privaatrecht in het financiële recht'). aangewezen route. In procedures bij de geschillencommissie van het Kifid beroepen consumenten zich (onder meer) op de verplichting van de bank zoals omschreven in de Wft. ${ }^{24}$ Er zijn mij geen zaken bekend bij de burgerlijke rechter waarin een consument een beroep doet op een van deze bepalingen inzake de basisbetaalrekening. In de Payment Account Directive (PAD) wordt ook nadrukkelijk ingezet op handhaving door de bevoegde autoriteiten en toegang voor consumenten tot effectieve en efficiënte alternatieve geschilbeslechting. ${ }^{25}$ In een enkele civiele uitspraak over opzegging of aangaan van een betaalrekening met zakelijke klanten is overigens wel een verwijzing naar de bepalingen inzake de basisbetaalrekening te vinden, ${ }^{26}$ maar dan is logischerwijze geen sprake van (directe) toepassing, omdat de bepalingen het recht op een basisbetaalrekening voor consumenten behelzen. ${ }^{27}$

\section{Opening en opzegging reguliere betaalrekening}

\subsection{Specifieke bepalingen $B W$}

De meeste rekeninghouders zullen een reguliere betaalrekening aanhouden en niet een basisbetaalrekening. Een basisbetaalrekening is niet hetzelfde als de reguliere betaalrekening die de meeste consumenten en bedrijven bij een bank aanhouden. De basisbetaalrekening is een minimumvoorziening waarbij de klant niet 'rood' kan staan. Bovendien staat zij alleen ter beschikking aan consumenten. De bepalingen uit de Wft die betrekking hebben op de basisbetaaldienst, gelden specifiek voor die dienst en niet ook voor andere betaalrekeningen. De weigerings- en opzeggingsgronden uit art. 4:71f Wft gelden dus niet zonder meer ook voor reguliere betaalrekeningen. Voor de voorwaarden om een reguliere betaalrekening op te zeggen dienen we te rade te gaan bij het civiele recht.

24. Of op de onderliggende Payment Account Directive, zie bijv. Kifid $2018 / 632$ of $2018 / 281$.

25. Art. 21 en 24 van de richtlijn, alsmede overwegingen 51 en 52 , PbEU 2014, L 257/214.

26. Zie bijv. Rb. Rotterdam (vzr.) 14 oktober 2019, ECLI:NL:RBROT: 2019:8534.

27. Ik neem aan dat een (aspirant-)klant van de bank geen direct beroep op de bepalingen uit de Wft kan doen in een civielrechtelijke zaak, daar deze publiekrechtelijke bepalingen gericht zijn tot de bank. De verplichtingen die de bank ten opzichte van de klant heeft, kunnen wel worden 'vertaald' naar een civielrechtelijke norm. Zo kan bijv. wellicht worden betoogd dat het weigeren van een basisbetaalrekening in strijd met art. 4:71f en 4:71g Wft een onrechtmatige daad oplevert. Evenwel lijkt deze 'route' momenteel niet van groot praktisch belang, anders dan bij civielrechtelijke zaken waarbij andere bepalingen inzake financieel gedragstoezicht aan de orde zijn, bijv. effectenleasezaken of renteswapzaken. De vraag in hoeverre de daar aan de orde zijnde bepalingen uit de Wft civielrechtelijke normen 'inkleuren', en of bijv. een civielrechtelijke zorgplicht verder mag gaan dan uit de Wft voortvloeit als de onderliggende richtlijn (MiFID I/II) maximumharmonisatie voorschrijft, laat ik hier rusten. Ik merk wel op dat de bepalingen inzake de basisbetaalrekeningen hun origine in een andere richtlijn vinden, de PAD, die minimumharmonisatie beoogt (overweging 11). 
Boek 7 BW kent in titel 7B een regeling van de betalingstransactie. Dit is een implementatie van de richtlijn betaaldiensten. ${ }^{28}$ De regeling is mede van toepassing op eenmalige betalingstransacties, maar ook op raamovereenkomsten en de daaronder vallende betalingstransacties (art. 7:515 lid 3 BW). De betalingstransactie is op zichzelf geen overeenkomst, maar er ligt wel een overeenkomst aan ten grondslag, eenmalig of een raamovereenkomst. Het gaat hierbij dus ook om een (raam)overeenkomst tussen een bank en een klant betreffende het aanhouden van een betaalrekening. Deze overeenkomst is volgens de wetgever geen overeenkomst van opdracht. Voorheen werd vrij algemeen aangenomen dat een overeenkomst met de bank inzake een betaalrekening wel als overeenkomst van opdracht kwalificeerde, ${ }^{29}$ maar de wetgever heeft aangegeven dat dit niet geldt voor de (raamovereenkomst inzake de) betalingstransactie. $\mathrm{Zij}$ wordt als een afzonderlijk benoemde overeenkomst beschouwd, verwant aan de overeenkomst van opdracht, maar zonder daarin op te kunnen gaan. ${ }^{30}$

Aan de totstandkoming van de raamovereenkomst betreffende een betaalrekening zijn geen bepalingen gewijd in titel $7.7 \mathrm{~B}$ BW. Hier gelden de gewone regels van wilsovereenstemming en aanbod en aanvaarding. Van Esch beschrijft de normale gang van zaken bij het openen van een betaalrekening. Daarbij zal de bank de identiteit van de klant willen vaststellen en ook een aantal controles uitoefenen. De bank is daartoe ook verplicht, bijvoorbeeld op grond van regelgeving die beoogt integriteitsrisico's en belastingontduiking tegen te gaan. ${ }^{31}$ Mede vanwege deze gang van zaken, waarbij de bank uiteindelijk beslist of zij de raamovereenkomst met deze klant al dan niet wil aangaan, concludeert Van Esch, mijns inziens terecht, dat de bank een uitnodiging tot het doen van een aanbod doet, bijvoorbeeld in reclame-uitingen. De potentiële klant doet een aanvraag om een rekening te openen, hetgeen als aanbod kan worden beschouwd, en de bank accepteert vervolgens. Op die wijze is dan voldaan aan de vereisten van een aanbod en aanvaarding daarvan (art. 6:217 lid 1 BW). De bank mag de klant weigeren, maar vanwege het grote maatschappelijke belang dat gemoeid is met het hebben van een betaalrekening, geldt ook voor een reguliere betaalrekening dat een weigeringsgrond de beslissing wel moet kunnen dragen. Er bestaat geen wettelijk recht op het aangaan van een reguliere betaalrekening, maar dat wil niet zeggen dat de contractvrijheid onbegrensd is. Dat

28. Richtlijn 2007/64/EG, ook wel aangeduid als Payment Services Directive. Het betreft de eerste versie, afgekort PSD1. Implementatiewet PSD1, Kamerstukken II 2008/09, 31892. Inmiddels is er een PSD2, Richtlijn (EU) 2015/2366. Zie over titel 7.7B BW, zoals deze luidt na de implementatie van PSD2, W.A.K. Rank, Betalingstransactie, in: H.N. Schelhaas \& A.J. Verheij (red.), Bijzondere overeenkomsten (Studiereeks Burgerlijk Recht 6), Deventer: Wolters Kluwer 2019, p. 361-428. Zie ook Rank, in: T\&C BW en T\&C Vermogensrecht, titel 7.7B BW.

29. Zie Rank $2019 / 350$.

30. Kamerstukken II 2008/09, 31892, nr. 3, p. 29, waarover kritisch: W.A.K. Rank, Betalingstransacties onder PSD2, MvV 2019, afl. 4, p. 111-112.

31. R.E. van Esch, Giraal betalingsverkeer, elektronisch betalingsverkeer (Recht en Praktijk, nr. FR7), Deventer: Wolters Kluwer 2019/7.3.1. bleek bijvoorbeeld in het in de inleiding reeds genoemde voorbeeld van ABN AMRO, die aan een cannabisteler geen bankrekening mocht weigeren. ${ }^{32}$

Art. 7:518 BW regelt de beëindiging van de raamovereenkomst. De betaaldienstgebruiker (lees: de klant) kan haar te allen tijde beëindigen. Wel kan een opzegtermijn van maximaal een maand zijn overeengekomen, die dan uiteraard geëerbiedigd moet worden. De betaaldienstverlener (lees in ons geval: de bank) kan de overeenkomst eveneens opzeggen. Daarvoor gelden enige voorwaarden. Opzegging door de bank is mogelijk indien:

a. dit in de overeenkomst is bepaald;

b. de opzegging schriftelijk geschiedt;

c. een minimale opzegtermijn van twee maanden in acht wordt genomen.

Art. 7:518 lid 3 BW ziet op opzegging van de raamovereenkomst. Andere wijzen van beëindigen, waarbij met name aan ontbinding kan worden gedacht, vallen er niet onder. Ontbinding is wel mogelijk op grond van art. 6:265 BW. Er dient dan sprake te zijn van een tekortkoming in de nakoming van de overeenkomst door de klant. Een dergelijke tekortkoming zou bijvoorbeeld gelegen kunnen zijn in niet-betaling van de kosten voor het gebruik van een betaalinstrument. ${ }^{33}$

Indien de klant consument is, kan niet ten nadele van die klant worden afgeweken van de opzeggingsregeling in art. 7:518 BW. Dat kan (dus) wel indien de klant geen consument is (art. 7:550 BW).

\subsection{Civielrechtelijke jurisprudentie opzegging reguliere betaalrekening}

\section{Algemeen kader}

In het voorgaande kwam aan de orde dat zowel de Wft als het BW regels stelt over de opzegging van een betaalrekening. De eerstgenoemde regeling ziet op de basisbetaalrekening, de tweede op de reguliere betaalrekening. Anders dan de Wft, geeft de regeling in het BW geen limitatieve opzeggingsgronden. Dat betekent evenwel niet dat een bank een reguliere betaalrekening zonder meer kan opzeggen.

Een raamovereenkomst betreffende betalingsdiensten is een duurovereenkomst. Voor duurovereenkomsten voor onbepaalde tijd geldt dat indien wet en overeenkomst niet voorzien in de opzegging, zij in beginsel opzegbaar zijn. De eisen van redelijkheid en billijkheid kunnen in verband met de aard en inhoud van de overeenkomst en de omstandigheden van het geval meebrengen dat opzegging slechts mogelijk is indien daarvoor een voldoende zwaarwegende grond bestaat, dan wel een voldoende lange opzegtermijn in acht is genomen of

32. Rb. Amsterdam (vzr.) 4 november 2019, ECLI:NL:RBAMS: 2019:8144.

33. Van Esch 2019/7.8. 
schadevergoeding is aangeboden. ${ }^{34}$ In dit geval zegt de wet wel iets over de opzeggingsbevoegdheid, in art. 7:518 BW. Deze bepaling refereert voor opzegging door de bank evenwel aan de in de overeenkomst opgenomen opzeggingsbevoegdheid en geeft geen inhoudelijke voorwaarden voor de opzegging. De overeenkomst met de bank bevat doorgaans een opzeggingsregeling, via de Algemene Bankvoorwaarden (ABV), die normaal gesproken deel uitmaken van de overeenkomst. Art. 35 ABV ziet op de opzegging van de bankrelatie, waaronder de betaaldienstverlening valt, en bepaalt dat beide partijen kunnen opzeggen. ${ }^{35}$ Desgevraagd geeft de bank de reden voor de opzegging. Voorwaarden die gelden voor opzegging, zoals een opzegtermijn of een opzeggingsgrond, worden door de bank in acht genomen en tevens dient de bank bij de opzegging de zorgplicht ex art. $2 \mathrm{ABV}$ in acht te nemen.

In beginsel bestaat er dus een opzeggingsbevoegdheid voor de bank, met dien verstande dat daarbij de zorgplicht in acht moet worden genomen. Bovendien kan uitoefening van de opzeggingsbevoegdheid naar maatstaven van redelijkheid en billijkheid onaanvaardbaar zijn (art. 6:248 lid 2 BW). ${ }^{36}$

De zorgplicht brengt met zich mee dat de bank bij de beslissing om al dan niet de overeenkomst op te zeggen, haar eigen belang dient af te wegen tegen het belang van de klant. De bank dient een zwaarwegend belang bij opzegging te hebben, daar in algemene zin het belang van de klant gelegen is in het zwaarwegende maatschappelijk belang bij toegang tot het betalingsverkeer. Indien de klant nog een rekening bij een andere bank heeft, is dat een omstandigheid die bij de belangenafweging in het voordeel van de bank is, omdat de klant dan niet volledig verstoken is van toegang tot het bancaire verkeer. Hierbij zij opgemerkt dat het bestaan van de regeling inzake een basisbetaalrekening geen vrijbrief is om het aangaan van een reguliere betaalrekening te weigeren, of deze op te zeggen. Zo staat de basisbetaalrekening alleen ter beschikking van consumenten. Een reguliere betaalrekening kan ook een zakelijke rekening betreffen.

\section{Integriteitsrisico's}

In de civielrechtelijke jurisprudentie over opzegging van overeenkomsten inzake betaalrekeningen spelen integriteitsrisico's voor de bank een grote rol. Een bank is bevoegd en soms zelfs verplicht om een rekening op te zeggen op grond van de toezichtswetgeving Wft en met name Wwft, indien er een risico bestaat op bijvoorbeeld witwassen of terrorismefinanciering. ${ }^{37}$ De verplichtingen ter zake van de banken zijn

34. HR 29 oktober 2011, ECLI:NL:HR:2011:BQ9854, NJ 2012/685 (Gemeente de Ronde Venen/Stedin).

35. Zie over de ABV nader A.G. Castermans \& R. de Graaff, Vernieuwde Algemene Bankvoorwaarden: begrijpelijk, evenwichtig, duurzaam, FR 2017, afl. 1-2, p. 12-20.

36. HR 10 oktober 2014, ECLI:NL:HR:2014:2929 (ING/De Keijzer Beheer c.s.).

37. Art. 3 jo. art. 5 jo. art. $8 \mathrm{Wwft}$. Zie over terrorismefinanciering $S$. Nanne $\&$ L. de Jong, Jihadstrijders en toegang tot een bankrekening, $\mathrm{TvCo}$ 2017, p. 160-168. met de invoering van de Wwft en de verschillende aanpassingen van deze wetgeving, alsmede door verscherpt toezicht door AFM en DNB, toegenomen. ${ }^{38}$ De vraag is hoe dit doorwerkt in de civielrechtelijke verhoudingen tussen de bank en de klant. Het zou er bijvoorbeeld toe kunnen leiden dat banken geneigd zijn om klanten die werkzaam zijn in sectoren met een verhoogd integriteitsrisico te weren. ${ }^{39}$ Van oudsher werden, ook voor invoering van de Wwft, betaalrekeningen op naam van bijvoorbeeld coffeeshops en sekssites opgezegd vanwege integriteitsrisico's, ${ }^{40}$ maar dergelijke risico's zijn niet tot die activiteiten beperkt. ${ }^{41}$

Een nieuwe loot aan de stam zijn bijvoorbeeld zaken over handelaren in cryptovaluta. Transacties in dergelijke valuta worden beschouwd als risicovol. De identiteit van de partijen die bitcoins aan- of verkopen, is moeilijk kenbaar, waardoor het risico van witwassen van uit misdrijf verkregen gelden via bitcoins op de loer ligt. Vanwege dit verhoogde integriteitsrisico ging bijvoorbeeld ING over tot opzegging van de overeenkomst betreffende een zakelijke bankrekening met een handelaar in bitcoins. ${ }^{42}$ De rechter acht deze opzegging naar maatstaven van redelijkheid en billijkheid niet onaanvaardbaar. Vanwege het hoge risicoprofiel mag de bank in beginsel van een bedrijf dat handelt in bitcoins verwachten dat hij onderzoek doet naar de identiteit van zijn klanten en naar de herkomst van de gelden waarmee hij bitcoins aankoopt. Twee grote klanten van de handelaar in bitcoins blijken encryptietelefoons en encryptiediensten te verkopen, producten en diensten die veelal door criminelen worden afgenomen. Dit makkt het risico dat het contante geld uit misdrijf is verkregen reëel. De rechter is van oordeel dat de klant zelf zijn zorgplicht jegens de bank heeft geschonden, door niet te stoppen met bitcointransacties in contanten en geen onderzoek te verrichten naar de identiteit en activiteiten van zijn twee grootste klanten. De bank heeft voldoende aannemelijk gemaakt dat zij door de niet-afdoende beantwoording van haar vragen niet aan de eisen die aan haar op grond van de Wft en Wwft worden gesteld, kan voldoen. Voortzetting van de relatie brengt een reëel reputatie- en integriteitsrisico met zich. De klant heeft overigens nog wel toegang tot het bancaire systeem, daar hij bij een andere bank kan bankieren. Een andere zaak betreft een klant die een digitaal handelsplatform voor crypto-

38. Kritisch over deze toegenomen rol van en controle op de banken ter voorkoming van witwassen: F. 't Hart, De bancaire strijd, AAe 2020, p. 539-543.

39. Zie hierover nader J. van Bekkum, Neveneffecten van de Wwft, FR 2020, afl. 3, p. 93-98, die van mening is dat banken tegenwoordig te makkelijk opzeggen met een beroep op de Wwft. Zie tevens, met name over de al dan niet houdbaarheid van opzeggen door banken vanwege fiscale integriteitsrisico's, S. van Norden, M. Ruigrok \& R.T. van Ginneken, De impact op de relatie tussen een bank en haar cliënt van DNB's 'Good Practices' ten aanzien van fiscale integriteitsrisico's, MvV 2019, afl. 12 , p. 432-438.

40. Van Esch 2019/7.8, met verwijzingen naar jurisprudentie.

41. Zie nader B. Bierens, Dilemma's rond de betaalrekening: opzeggen of voortzetten? De belangen van de bank en de cliënt met een verhoogd integriteitsrisico gewogen, NTBR 2010, afl. 2, p. 2-10.

42. Rb. Amsterdam (vzr.) 16 november 2017, ECLI:NL:RBAMS: 2017:8376, JOR 2018/43 m.nt. Wijnstekers. 
currencies exploiteert. ${ }^{43}$ In januari 2018 is door Bunq een bankrekening geopend ten behoeve van de klant, maar vervolgens laat Bunq in maart al aan de klant weten de bancaire relatie te zullen beëindigen vanwege een gewijzigd risicoprofiel. De rechter acht het ook in dit geval naar maatstaven van redelijkheid en billijkheid niet onaanvaardbaar dat de bank van haar contractuele opzeggingsbevoegdheid gebruik maakt, nu de acceptatie door de bank een voorwaardelijk karakter had. De bank heeft namelijk van het begin af aan vragen gesteld om de risico-inschatting te kunnen maken. Bovendien had de bancaire relatie nog nauwelijks gestalte gekregen. Het oordeel dat opzegging niet onaanvaardbaar is, ligt volgens de rechter te meer voor de hand nu de beoogde activiteiten van de klant risicovol van aard zijn. Met name het verrichten van initial coin offerings (ICO's) wordt als zeer risicovol aangemerkt. ${ }^{44}$

Een bank mag dus een overeenkomst opzeggen vanwege een te hoog integriteitsrisico. De bank dient dit integriteitsrisico wel aannemelijk te maken, voor deze individuele klant. Enkel het feit dat een klant in een bepaalde branche werkzaam is, is daartoe niet voldoende. ${ }^{45}$ De omstandigheden van het specifieke geval moeten hierbij in ogenschouw worden genomen. Blijkt van een voldoende reëel risico, dan is opzegging doorgaans geoorloofd. ${ }^{46}$

\section{Verzoek om informatie}

Soms is niet meteen duidelijk of er sprake is van een voldoende concreet risico. Dit kan voor de bank aanleiding vormen tot het doen van (nader) onderzoek, waarbij de klant desgevraagd informatie dient aan te leveren. Deze informatieplicht staat ook in art. $3 \mathrm{ABV}$, dat bepaalt dat een rekeninghouder desgevraagd informatie aan de bank dient te verstrekken, teneinde misbruik te voorkomen en risico's te beoordelen. Het betreft informatie over de activiteiten en doelen van de klant, waarom een product of dienst wordt afgenomen en wat de herkomst is van het geld, waardepapieren en andere zaken die de klant bij of via de bank onderbrengt. Ook worden specifiek genoemd gegevens die nodig zijn om te bepalen van welk land de reke-

43. Opzegging door de bank niet onaanvaardbaar in de zin van art. 6:248 lid 2 BW in: Rb. Amsterdam (vzr.) 4 juli 2018, ECLI:NL:RBAMS: 2018:5550, JOR 2018/251, m.nt. Wijnstekers.

44. Zie bijv. Position paper AFM Hoorzitting cryptocurrencies, 24 januari 2018; Position paper DNB rondetafelgesprek Cryptocurrencies/ICO's, 24 januari 2018; A.B. Schoonbeek \& J.M. van Poelgeest, Nadere beschouwing over witwasrisico's bij gebruik van cryptovaluta en de impact van regulering, TvCo 2020, p. 93-103, met nadere verwijzingen naar onder meer rapporten die de risico's van witwassen in kaart brengen en de regelgeving, met name de implementatie van de vijfde witwasrichtlijn, die exchanges binnen het bereik van de Wwft zullen brengen.

45. Zie bijv. Hof 's-Hertogenbosch 10 mei 2011, ECLI:NL:GHSHE: 2011:BQ4141: het enkele feit dat een bestaande klant een coffeeshop exploiteert, is niet voldoende grond voor opzegging; vgl. Gem. Hof 15 mei 2020, ECLI:NL:LOGHACMB:2020:134 inzake het verhoogde risicoprofiel van casino's.

46. Hof Amsterdam 19 januari 2018, ECLI:NL:GHAMS:2018:281; Hof Arnhem-Leeuwarden 12 februari 2019, ECLI:NL:GHARL:2019:1327; Rb. Amsterdam (vzr.) 5 augustus 2019, ECLI:NL:RBAMS:2019:5721. ninghouder fiscaal inwoner is. Art. $7 \mathrm{ABV}$ gaat over informatie die nodig is om de identiteit van een klant te controleren. Het niet voldoen door een klant aan gerechtvaardigde verzoeken om informatie kan reden zijn om de overeenkomst op te zeggen, de bank kan dan immers niet aan haar verplichtingen uit hoofde van de toezichtswetgeving voldoen. ${ }^{47}$ Dit argument kwam al aan de orde in de hiervoor besproken zaak inzake de opzegging van de rekening van een handelaar in bitcoins. Het verzoek om informatie kan echter ook te vergaand zijn, in die zin dat er te veel eigen onderzoek van de klant wordt gevergd. ${ }^{48}$ Een voorbeeld is een zaak waarin een klant bij de opening van de bankrekening had aangegeven te handelen in gebruikte auto-onderdelen. De gerealiseerde omzet bleek veel hoger dan verwacht, waarop de klant door Rabobank is verzocht informatie te verschaffen over de activiteiten. Vervolgens bleek dat de activiteiten waren gewijzigd in handel in kleine elektronica. De bank zegt de overeenkomst op met als reden dat de klant niet kan vaststellen waar de producten vandaan komen, en dus het risico loopt zich schuldig te maken aan handel in gestolen goederen. De Rabobank wil desgevraagd de opzegging wel heroverwegen, maar stelt daarvoor eisen aan de klant die er kort gezegd op neerkomen dat de klant zijn eigen klanten moet onderwerpen aan een 'know your costumer' (KYC)-onderzoek. De rechter in kort geding is van oordeel dat de Wwft in dit geval niet verplicht tot opzegging van de overeenkomst. De bank heeft weliswaar concrete indicaties van betrokkenheid bij witwassen geconstateerd, bestaande uit de hoge omzet en opvallende afnemers, leveranciers en financiers van de klant, die niets met kleine consumentenelektronica te maken lijken te hebben, maar de klant heeft hier afdoende verklaringen voor gegeven. De rechter acht de geëiste KYC-onderzoeken, zonder concrete aanwijzingen dat er daadwerkelijk iets mis is, buitenproportioneel. Een algemene notie dat deze branche een hoog risicoprofiel heeft, is niet voldoende. Het niet uit zichzelf vermelden van een wijziging van de goederen waarin wordt gehandeld, wordt in dit geval niet zo ernstig geacht dat het tot opzegging zou moeten leiden.

Indien er een concrete aanleiding is om te veronderstellen dat er iets mis is met de transacties of klanten van de klant en vragen hierover worden niet afdoende beantwoord, dan is een opzegging wel geoorloofd. Zo zegde ING een overeenkomst met een aantal klanten op naar aanleiding van berichten in de Franse krant Le Monde, niet over de klanten zelf, maar over een belangrijke handelspartner van die klanten. ${ }^{49}$ Het betrof berichtgeving over veroordelingen en een lopend onderzoek vanwege fraude en oneerlijke handelspraktijken. De bank stelt naar aanleiding hiervan vragen aan haar klanten, die traag en onvolledig worden beantwoord. In deze omstandigheden is

47. Zie bijv. Rb. Amsterdam (vzr.) 7 mei 2019, ECLI:NL:RBAMS 2019:3352. Bierens 2010.

48. Rb. Amsterdam (vzr.) 30 april 2019, ECLI:NL:RBAMS:2019:3157, JOR 2019/227, en de instructieve noot inzake informatieverzoeken van T. Hekman daarbij.

49. Meer specifiek de Ultimate Beneficial Owner (UBO). 
het gebruik maken van de opzeggingsbevoegdheid naar maatstaven van redelijkheid en billijkheid niet onaanvaardbaar. ${ }^{50}$

\section{Conclusie}

Een bank is in beginsel verplicht een betaalrekening te openen ten behoeve van degene die daarom vraagt. De reden voor deze inbreuk op de contractvrijheid van de bank is het grote maatschappelijk belang dat gemoeid is met het hebben van toegang tot het betalingsverkeer. Het betalingsverkeer heeft na de Tweede Wereldoorlog en sinds de wederopbouw zo'n hoge vlucht genomen dat, in ieder geval in Europa, deelname aan het maatschappelijk verkeer niet langer mogelijk is zonder toegang tot een betaalrekening. Dat geldt voor consumenten en daarvoor is een wettelijke regeling van Europese origine in de vorm van de basisbetaalrekening ingevoerd, maar dat geldt ook voor (aspirant-)rekeninghouders die geen consument zijn. Ook voor die laatste categorie geldt dat de bank in beginsel verplicht is een betaalrekening te openen. De ratio achter deze vorm van contractdwang, het grote belang dat voor de burger of een bedrijf gemoeid is met het gebruik kunnen maken van een betaalrekening, is ook de achtergrond van de beperking van de opzeggingsbevoegdheid van de bank. De bank heeft het recht om een overeenkomst inzake een betaalrekening op te zeggen, veelal op basis van een clausule in de overeenkomst, maar dat recht is zeker niet onvoorwaardelijk. Het contract, meer specifiek de ABV, koppelt de opzegging aan de zorgplicht van de bank. De bank bindt zichzelf dus om bij de opzegging haar zorgplicht in acht te nemen.

De opzeggingsgronden voor de basisbetaalrekening staan in de Wft opgesomd. Voor wat betreft andere betaalrekeningen dan een basisbetaalrekening geldt dat er geen opzeggingsgronden in de wet staan, maar dat uit de civielrechtelijke jurisprudentie valt af te leiden dat de bank een zwaarwegend belang bij de opzegging dient te hebben. De beperkingen aan de opzeggingsbevoegdheid van de bank kunnen de bank in een moeilijke positie plaatsen, indien twee belangen om voorrang strijden. De bank is in ieder geval niet vrij om zonder meer haar eigen acceptatie- en opzeggingsbeleid te voeren; zij dient zich daarbij te houden an toezichtswetgeving. Van een bank wordt ook verwacht dat zij een actieve rol vervult bij onder meer het tegengaan van bepaalde vormen van criminaliteit. De spanning die er voor banken kan ontstaan tussen het eigen - maar ook het maatschappelijk - belang van het voldoen aan internationale afspraken en toezichtswetgeving om onder meer belastingontduiking, witwassen en terrorismefinanciering tegen te gaan, en het belang van de individuele klant die niet zonder betaalrekening kan functioneren, wordt in concrete casus bij uitstek zichtbaar. Ik durf de stelling wel aan dat ondanks de toegenomen druk op de banken om een rol te spelen in de bestrijding van voornoemde praktijken, de civielrechtelijke conclusie nog immer luidt: bij twijfel niet opzeggen. De ratio van de contractdwang voor banken werkt door in het

50. Rb. Amsterdam (vzr.) 7 mei 2019, ECLI:NL:RBAMS:2019:3352 concrete geval en leidt ertoe dat in twijfelgevallen het belang van de individuele klant prevaleert. ${ }^{51}$
51. Vgl. J.W. Achterberg, Het spanningsveld tussen een integere bancaire sector en laagdrempelige toegang tot het betalingsverkeer, MvV 2011, afl. 2, p. 41-50. 